\title{
MENYINGKAP SISI GELAP PENDIDIKAN SEBAGAI ARENA REPRODUKSI KESENJANGAN SOSIAL BERDASARKAN PERSPEKTIF PIERRE BOURDIEU
}

\section{Ardyanto Allolayuk}

Universitas Sanata Dharma (USD) Yogyakarta, Indonesia

Email: allolayuka@gmail.com

\begin{abstract}
Abstrak
Pendidikan dipandang sebagai sarana mobilitas sosial bagi seluruh masyarakat, khususnya peserta didik dari kelompok sosial kelas bawah. Fungsi pendidikan sebagai sarana mobilitas sosial hanya dapat diwujudkan ketika institusi pendidikan formal membuka kesempatan yang sama bagi peserta didik, tanpa membedakan asal-usul sosial peserta didik. Penelitian ini bertujuan untuk menyingkapkan sistem reproduksi kesenjangan sosial dalam pendidikan yang menjadi penyebab ketidakadilan. Penelitian ini menggunakan metode studi pustaka dan menghasilkan kesimpulan akan pentingnya kerja sama yang sinergi antara peserta didik, guru, keluarga, pemerintah, dan masyarakat dalam dunia pendidikan. Pemerintah dan seluruh warga harus mengupayakan berbagai langkah yang dapat mengatasi hambatan yang sering dijumpai peserta didik kelas bawah. Berbagai usaha bersama diharapkan mampu semakin membuka kesempatan yang sama bagi semua peserta didik dalam "arena" pendidikan, sehingga pendidikan dapat sungguh menjadi sarana mobilitas sosial peserta didik.
\end{abstract}

Kata Kunci: pendidikan; reproduksi kesenjangan sosial; kapital

\section{Abstract}

Education is seen as a means of social mobility for the whole community, especially students from lower class social groups. The function of education as a means of social mobility can only be realized when formal educational institutions open equal opportunities for students, regardless of the social origins of students. This study aims to reveal the reproductive system of social inequality in education that is the cause of injustice. This research uses the literature study method and concludes on the importance of synergistic cooperation between students, teachers, families, government, and the community in the world of education. The government and all citizens must seek various steps that can overcome the obstacles that are often encountered by lower class students. Various joint efforts are expected to be able to open up equal opportunities for all students in the "arena" of education, so that education can truly become a means of social mobility for students.

Keywords: education; social reproduction; field

$\begin{array}{ll}\text { How to cite: } & \text { Allolayuk, A. (2021) Menyingkap Sisi Gelap Pendidikan Sebagai Arena Reproduksi Kesenjangan } \\ & \text { Sosial Berdasarkan Perspektif Pierre Bourdieu, Syntax Idea, 3(8), https://doi.org/10.36418/syntax- } \\ & \text { idea.v3i8.1407 } \\ \text { E-ISSN: } & 2684-883 \mathrm{X} \\ \text { Published by: } & \text { Ridwan Institute }\end{array}$




\section{Pendahuluan}

Pendidikan merupakan salah satu indikator yang dapat digunakan untuk mengetahui perkembangan dan kemajuan suatu bangsa. Tingkat dan kualitas pendidikan mempunyai pengaruh yang signifikan terhadap perkembangan peradaban suatu bangsa. Pendidikan menjadi suatu kebutuhan penting dan mendesak yang semestinya menjadi hak sekaligus kewajiban setiap orang yang menginginkan perubahan. Melalui pendidikan, setiap orang diharapkan mampu menjadi agen atau pelaku perubahan sosial. Akan tetapi, dalam realitanya banyak kasus dalam bidang pendidikan yang menunjukkan kurangnya integrasi dan sinergisitas dalam pengembangan pendidikan. Pertarungan Bourdieu dengan pendidikan menampakkan sebuah tantangan penting yang mengandung relevansi karya Bourdieu dan hubungannya dengan karya pendidikan di berbagai negara. Penerimaan Bourdieu dalam tradisi penelitian pendidikan yang berbeda mengungkapkan variasi pandangan nasional yang berbeda pula (Rawolle \& Lingard, 2013). Pierre Felix Bourdieu merupakan seorang Profesor Sosiologi College de France, lahir pada tanggal 1 Agustus 1930 di daerah Denguin, sebuah desa di distrik Pyreness-Atlantiques, Barat Daya Prancis. Perkembangan gagasan sosiologinya mendapat pengaruh secara negatif dari eksistensialisme Sartre (Palmer \& Cooper, 2013), fenomenologi Husserl (Bertens, 2014), strukturalisme (Lubis, 2014), Sosiologi Weber (Weber, 2012). Mengacu pada konsep Bourdieu tentang kapital dan arena (Purwanto, 2016), fenomena ini dapat dinilai sebagai dampak dari kurangnya kepemilikan kapital (Bertens, 2014), khususnya kapital budaya sehingga mereka tidak siap bersaing dalam proses perkuliahan. Ketidaksiapan ini berdampak pada pertaruhan yang sejak awal mereka lakukan dalam arena pendidikan formal, yakni kepemilikan kapital, khususnya kapital budaya (Nikmah, 2020) dan simbolik dapat menjamin posisi sosial mereka di masa depan. Kegagalan mereka dalam pendidikan menandakan status mereka sebagai kelompok yang didominasi oleh mereka yang berhasil dalam pendidikan (kelompok yang mendominasi). Problematika dunia pendidikan tidak hanya terbatas pada situasi dominasi. Penulis menyadari ada masalah yang sangat besar dalam pendidikan Indonesia saat ini, yakni pendidikan menjadi arena representasi dan mereproduksi kesenjangan sosial. Hal ini berarti pendidikan menjadi tempat, di mana sebagian besar orang justru merepresentasikan posisi sosialnya.

Gagasan mengenai kapital sangat erat kaitannya dengan khazanah ilmu ekonomi, namun Bourdieu menggunakan gagasan 'kapital' dalam pemikirannya mengenai dominasi, karena beberapa cirinya yang mampu menjelaskan hubungan-hubungan kekuasaan (Poulin Jessica, 2015) antara lain: 1) kapital terakumulasi melalui investasi; 2) kapital bisa diberikan kepada yang lain melalui warisan; 3) kapital dapat memberi keuntungan sesuai dengan kesempatan yang dimiliki oleh pemiliknya untuk mengoperasikan penempatannya (Haryatmoko, 2016). Gagasan Bourdieu mengenai dukungan kapital budaya yang sangat signifikan dalam arena pendidikan formal menginspirasi penulis untuk mencermati fenomena tentang sulitnya kelompok masyarakat yang terdominasi, entah karena ekonomi dan status sosial sebagai golongan menengah ke bawah, entah karena terdominasi sebagai suku atau agama, atau pun ras 
yang minoritas- untuk masuk dalam sekolah atau universitas negeri terbaik di Indonesia. Berhadapan dengan persoalan ini, penulis berasumsi bahwa kesempatan untuk menempuh pendidikan di universitas terbaik dipengaruhi oleh kepemilikan kapital, khususnya kapital budaya dan kapital ekonomi. Semakin besar kepemilikan kapital, maka kesempatan dan akses ke sekolah atau universitas terbaik akan semakin terbuka. Sebaliknya, semakin rendahnya kepemilikan kapital, maka kesempatan dan akses pun semakin kecil, bahkan nihil. Masyarakat perlu menyadari bahwa dalam situasi tersebut bukan hanya dukungan kapital budaya yang dibutuhkan, melainkan juga dukungan kapital sosial (Suyanto, Bagong, 2013) dan kapital ekonomi (Suyanto, Bagong, 2013). Misalnya, ketika ada 1.000 calon mahasiswa mendaftar di sebuah universitas terbaik Indonesia dengan kuota penerimaan mahasiswa baru hanya 300 orang, maka jelaslah para pendaftar yang akan terpilih adalah yang memiliki kapital lebih besar dibandingkan yang lain. Kapital-kapital tersebut harus saling mendukung. Contohnya, seorang yang cerdas harus pula didukung oleh kemampuan ekonomi yang baik (mempunyai banyak uang) dan menjalin berbagai relasi sosial yang dapat menentukan kedudukan atau keberhasilannya (orang tuanya merupakan rekan bisnis dari rektor universitas tersebut).

Berdasarkan pada studi penelitian terdahulu yang dilakukan oleh EnyWahyu Suryatnti dan Febi Dwi Widayanti dengan judul Penguatan Pendidikan Karakter Berbasis Religius. Pada penelitian terdahulu menyatakan bahwa sudah banyak kasus kemerosotan karakter dalam dunia pendidikan, oleh sebab itu maka dibutuhkan suatu penanaman karakter sejak dini baik dilingkungan keluarga maupun dilingkungan sekolah (Zulaikhah, 2019).

Pierre Bourdieu, seorang tokoh ilmu sosial yang mengharuskan ilmu sosial agar mampu menganalisis mekanisme dominasi agar bisa menjadi instrumen pembebasan bagi golongan yang didominasi telah menginspirasi penulis untuk mempelajari berbagai gagasan dan kritiknya terhadap dunia pendidikan formal yang menjadi sarana reproduksi kesenjangan sosial. Pembelajaran tersebut menghasilkan suatu kebaruan dalam pendidikan yang merujuk pada sinergisitas peran peserta didik, orang tua, pemerintah, dan masyarakat umum.

\section{Metode Penelitian}

Penulisan karya tulis ini menggunakan metode penelitian pustaka (library research). Metode ini merujuk pada kegiatan pengumpulan data, melalui proses membaca berbagai literatur yang berkaitan dengan tema reproduksi sosial dalam pendidikan. Prosedur pengumpulan data yang dilakukan melalui tiga tahap utama, yakni tahap orientasi, tahap eksplorasi, dan tahap studi terfokus. Tahap orientasi merupakan tahap yang digunakan penulis untuk mengumpulkan data secara umum tentang Boerdieu dan karya-karyanya. Tahap eksplorasi merupakan tahap yang berkaitan dengan proses pengumpulan data yang terarat pada fokus penelitian, sementara itu tahap studi terfokus merupakan tahap yang digunakan penulis untuk mengkaji fokus penelitian, yakni reproduksi kesenjangan sosial dalam pendidikan. Setelah menyelesaikan proses pengumpulan data, penulis akan mengolahnya sehingga 
menghasilkan suatu kesimpulan. Teknik analisis data yang digunakn dalam karya tulis ini adalah deskriptif analitik. Penulis akan menguraikan sekaligus menganalisis data yang telah terkumpul sehingga mendapatkan hasil yang memuaskan.

\section{Hasil dan Pembahasan}

\section{Reproduksi Kesenjangan Sosial dalam Pendidikan}

Pendidikan diklaim sebagai sarana mobilitas sosial yang membuka kesempatan yang sama bagi semua peserta didik. Masyarakat meyakini bahwa pendidikan dapat menjadi suatu sarana untuk meningkatkan kompetensi dan keterampilan peserta didik. Peningkatan kualitas peserta didik memberikan peluang keberhasilan yang semakin besar. Keyakinan dan harapan ini selalu dipegamg teguh oleh masyarakat, bahkan hingga zaman ini. Akan tetapi, keyakinan akan kesempatan yang sama bagi semua peserta didik dalam pendidikan untuk mobilisasi sosial ditentang oleh Bourdieu. Penelitian yang dilakukan oleh Bourdieu dan Passeron tentang institusi pendidikan di Prancis, khususnya Perguruan Tinggi, menyingkapkan sisi gelap yang selama ini terselubung.

Bourdieu dan Passeron membuka selubung hubungan dominasi yang terjadi dalam pendidikan. Hubungan dominasi ini merupakan konsekuensi dari perbedaan kapital peserta didik, khususnya kapital budaya, antara lain kebiasaan membaca, keterampilan menggunakan bahasa ilmiah dan asing, dan habitus (contoh: ketekunan, kejujuran, dan kedisiplinan). Habitus sebagai suatu produk sejarah yang menghasilkan praksis individual dan kolektif mengindikasikan aktivitas masyarakat untuk menciptakan sejarahnya sendiri, meskipun tidak selalu didasari atas pilihan mereka sendiri, karena dunia objektif dan cara pandang masyarakat pun merupakan produk dari praksis masa lalu, dari generasi sebelumnya (Purwanto, 2016). Kebiasaan-kebiasaan ini ditanamkan dalam keluarga dan umumnya dilakukan oleh mereka yang termasuk kelas sosial atas. Peserta didik yang berasal dari keluarga kelas bawah umumnya tidak memiliki kebiasaan-kebiasaan tersebut.

Perbedaan kepemilikan kapital budaya yang menyebabkan kesenjangan sosial semakin dirasakan para peserta didik. Mereka yang mempunyai kapital budaya lebih besar akan menjadi kelompok yang mendominasi, sementara yang lain menjadi kelompok terdominasi. Contoh, kemampuan menggunakan media dan fasilitas modern serta mengakses jaringan internet. Seorang siswa yang mampu mengoperasikan berbagai aplikasi PC dan dengan mudah mengakses jaringan internet akan lebih mudah mengembangkan dirinya dan memenangkan persaingan dalam pendidikan, dibandingkan siswa yang tidak mampu mengoperasikan aplikasi PC dengan baik dan kesulitan dalam mengakses jaringan internet.

Perbedaan pewarisan kapital budaya akan memengaruhi perjalanan peserta didik dalam institusi pendidikan formal. Peserta didik kelas atas yang telah mempunyai kebiasaan-kebiasaaan yang dituntut oleh budaya sekolah akan lebih mudah beradaptasi dengan lingkungan pendidikan. Kesesuaian kebiasaan yang telah ditanamkan dalam diri para peserta didik kelas atas sesuai dengan tuntutan budaya 
sekolah sehingga mereka siap menghadapi persaingan dalam "arena" pendidikan formal. Sedangkan, peserta didik kelas bawah merasa asing dengan kebiasaan tersebut sehingga sulit untuk beradaptasi dengan tuntutan budaya sekolah. Peserta didik kelas bawah bahkan cenderung merasa asing dengan budaya sekolah, sehingga mengeliminasi diri sendiri. Faktor ini yang dapat menyebabkan peserta didik akhirnya putus sekolah.

Bourdieu mengungkapkan adanya hubungan antara pihak sekolah yang dipahami sebagai lembaga reproduksi budaya yang berlaku, dan kelas-kelas sosial yang ditandai oleh kemampuan menyerap komunikasi pedagogis secara efektif. Kemampuan peserta didik kelas sosial atas menyerap komunikasi pedagogis dalam institusi pendidikan formal tidak dapat dilepaskan dari dukungan kebiasaan yang telah ditumbuhkan sejak awal dalam keluarga, sehingga mereka dekat dengan budaya sekolah dan menjadi cara untuk mempertahankan posisi mereka. Berbeda dengan peserta didik dari kelas sosial bawah yang kurang mampu menyerap komunikasi pedagogis secara efektif. Perbedaan ini pun berdampak pada persaingan kelas sosial atas dan kelas sosial bawah. Sistem reproduksi dalam institusi pendidikan formal tidak hanya terkait dengan kapital budaya, tetapi juga kapital ekonomi. Dukungan kapital ekonomi semakin memberikan ruang dominasi yang lebih besar bagi peserta didik yang memiliki kapital budaya sangat baik. Dengan adanya dukungan kapital budaya dan kapital ekonomi, maka semakin terbuka kesempatan bagi kelompok atau elite penguasa untuk semakin mendominasi dan tindakan tersebut dibenarkan sebagai sesuatu yang mencakup kemampuan intelektual yang superior.

\section{Doxa: Kesempatan Sama dalam Pendidikan}

Sekolah dipandang sebagai sarana yang membuka kesempatan yang sama bagi semua peserta didik. Pandangan ini lahir dari kelompok dominan yang diterima begitu saja oleh kelompok terdominasi. Upaya yang dilakukan untuk mendukung gagasan ini adalah dengan menampilkan tokoh sukses dalam kehidupannya berkat pendidikan yang berasal dari latar belakang keluarga kelas bawah, contohnya George Pompidou, Presiden Prancis, yang merupakan cucu seorang petani dan anak seorang guru dari desa Cantal. Langkah ini merupakan strategi yang digunakan untuk semakin mempertahankan posisi kelas dominan dalam "arena" pendidikan formal. Kelompok terdominasi umumnya tertipu oleh cara ini, tanpa memikirkan persentase keberhasilan dari peserta didik kelas bawah. Bourdieu mencatat bahwa kemampuan bersaing peserta didik kelas atas jauh lebih tinggi dibandingkan peserta didik kelas bawah. Dia memberikan angka $76 \%$ untuk peserta didik kelas atas yang dinilai maju, sedangkan peserta didik kelas bawah hanya berkisah 36\%. Itu berarti $64 \%$ peserta didik kelas bawah dianggap terlambat berkembang dalam pendidikan formal.

Masyarakat umum menganggap bahwa persaingan dalam "arena" pendidikan formal dimulai oleh para peserta didik dari titik yang sama. Padahal, para peserta didik memulai persaingan dari titik yang berbeda. Perbedaan ini diakibatkan perbedaan kepemilikan kapital mereka, utamanya kapital budaya yang diterima dalam keluarga. Kapital budaya yang sangat penting dirasakan peranannya 
kemampuan berbahasa. Bahasa bukan sekadar alat komunikasi, melainkan mendukung sistem kategori, kemampuan penjelasan dan manipulasi dengan struktur kompleks, logis atau estetis, yang sebagian tergantung dari kekayaan bahasa yang diajarkan oleh keluarga (Penegasan ini menjadi jelas dirasakan saat tahun-tahun pertama memasuki "arena" pendidikan formal. Kemampuan berbahasa peserta didik tidak dapat dilepaskan dari asal kelas sosial mereka. Bourdieu dan Passeron menyatakan bahwa hanya dalam bidang ilmu eksakta keberhasilan peserta didik tidak dapat langsung dikaitkan dengan asal usul kelas sosial karena tuntutan terhadap keterampilan berbahasa dalam bidang eksakta bukanlah tekanan utama (Rusdiarti, 2003). Pengaruh latar belakang sosial ini sangat berperan sebab keluarga menjadi tempat pewarisan budaya dan pembetukan habitus primer. Meskipun diwariskan, namun habitus senantiasa merupakan hasil konstruksi ketimbang pemberian (Edkins, Williams, \& Radike, 2010). Para peserta didik kelas bawah tidak mempunyai kemampuan, keterampilan, dan habitus yang berlaku dalam budaya sekolah. Berbeda dengan peserta didik kelas atas yang diuntungkan dengan keluarga yang terbiasa melakukan kegiatan yang dekat dengan budaya sekolah. Sejak awal, mereka telah diwarisi kapital budaya dan habitus sehingga lebih cepat menyesuaikan diri dengan budaya sekolah, lebih siap dalam bersaing, dan merasa sebagai bagian dari budaya sekolah, karena itu cenderung melanggengkan privilese mereka. Habitus di sini menjadi proses internalisasi sturktur dunia sosial, atau struktur sosial yang dibatinkan (Fashri, 2014). Pandangan yang mereduksi kelas sosial hanya sebagai masalah ekonomi atau hubungan produksi ditolak oleh Bourdieu, karena itulah dia mendefinisikannya sebagai habitus (Ritzer, 2012).

Penelitian yang dilakukan Bourdieu dan Passeron terhadap sistem pendidikan yang berlaku di Prancis dengan menggunakan pendekatan sosiologi telah menyingkapkan selubung dominasi dalam sistem pendidikan, khususnya keyakinan teguh masyarakat akan pendidikan yang memberikan kesempatan yang sama bagi semua golongan. Masyarakat kurang menyadari bahwa sejak hendak masuk dunia pendidikan formal, berbagai kriteria yang diberikan oleh sekolah tertentu. Kriteriakriteria mesti dipenuhi oleh para calon peserta didik kalau ingin bergabung dengan sekolah tertentu sesuai dengan kebijakan yang telah ditetapkan sekolah tersebut. Situasi ini menampilkan persaingan di antara para calon peserta didik, karena itu mereka yang lebih siap mengahadapi persaingan ini akan mempunyai peluang lebih besar untuk memenangkannya. Kesiapan ini ditandai dengan kepemilikan kapital budaya, berupa pengetahuan, habitus yang sesuai dengan lingkungan sekolah, dan keterampilan berbahasa serta menggunakan berbagai media pembelajaran modern. Habitus berfungsi untuk menyarankan agar agen menentukan apa yang seharusnya dipikirkan dan dilakukan (Syaeful, Bahar 2013). Di satu sisi, praksis diproduksi dalam dan melalui interaksi antara habitus dan disposisinya (Karnanta, 2013) dan di sisi lain desakan, tuntutan dan kesempatan "arena" sosial atau pasar yang sesuai dengan habitus atau dalam pergerakan/perubahan aktor.

\section{Meningkatkan Strategi Pendidikan dalam Keluarga}


Berbagai fenomena yang mewarnai pendidikan Indonesia menyingkapkan kenyataan bahwa masih terdapat banyak permasalahan dalam bidang pendidikan. Ketidakadilan dalam pendidikan, diskriminasi, komersialisasi pendidikan, terlalu berfokus pada pendekatan kurikulum, sehingga mengabaikan pendekatan sosiologi, dan tingginya angka putus sekolah merupakan berbagai permasalahan yang mesti ditangani secara cepat dan serius. Persoalan kegagalan peserta didik dalam pendidikan yang pada akhirnya membuat mereka memilih untuk berhenti bersekolah, tidak melulu terjadi karena soal ekonomi (ketidakmampuan membayar uang sekolah). Akan tetapi, penulis melihat bahwa kegagalan ini justru terjadi karena ketidakmampuan peserta didik beradaptasi dengan lingkungan sekolah. Para peserta didik tidak mempunyai habitus yang dituntut oleh lingkungan sekolah, sehingga merasa asing dan bukan bagian dari lingkungan sekolah. Peserta didik sebagai individu mesti menyadari bahwa mereka bukanlah agen yang sepenuhnya bebas sekaligus bukan produk pasif dari struktur sosial (Siregar, 2016). Bourdieu melihat fenomena semacam ini, sebagai kegagalan pewarisan budaya. Kegagalan atau keberhasilan pewarisan budaya kepada peserta didik dalam keluarga, sesungguhnya merupakan faktor yang berpengaruh cukup besar bagi peserta didik di lingkungan sekolah. Pewarisan kapital budaya dalam keluarga meliputi budaya keluarga, habitus bahasa, kebiasaan diskusi, menulis buku harian, ketersediaan ruang baca, perpustakaan, kamus, ensiklopedi, dan arah orientasi sosial. Berbagai bentuk kapital budaya yang diwariskan dalam keluarga, tentu saja tidak sama. Keluarga dokter, pengacara, guru, polisi mempunyai strategi pendidikan yang lebih baik dibandingkan oleh keluarga buruh dan petani. Peserta didik dari keluarga petani, sangat jarang dibekali dengan kebiasaan membaca dan habitus bahasa, sedangkan peserta didik dari keluarga dokter, sejak awal terbiasa dengan kegiatan membaca dan bahasa baku, ilmiah, atau asing. Contoh, dalam keluarga dokter, ada kebiasaan berkomunikasi menggunakan bahasa Inggris, sedangkan keluarga petani tidak pernah mempunyai kebiasaan berkomunikasi dalam keluarga dengan menggunakan bahasa Inggris.

Gagasan Bourdieu mengenai keluarga yang menjadi basis strategi pendidikan seharusnya menyadarkan masyarakat akan tugas penting orang tua bagi perkembangan pendidikan anak, utamanya dalam pewarisan kapital budaya. Keluarga, melalui strategi pendidikan dapat mempersiapkan anak yang siap bersaing dan kompeten dalam arena pendidikan formal yang akan dimasukinya. Melalui cara ini, anak dapat dipersiapkan sebagai pelaku perubahan jenjang sosial keluarga. Contoh, seorang anak dalam keluarga petani harus dibiasakan untuk membaca buku. Di zaman ini buku bukanlah barang mahal dan langka didapatkan, sehingga bisa diakses oleh semua orang. Dengan menanamkan kebiasaan seperti ini, anak lebih siap mengahadapi persaingan dalam "arena" pendidikan formal dan tidak merasa sebagai bagi terpisahkan atau asing dengan habitus yang dituntut oleh sekolah. Akan tetapi, perlu dipahami bahwa penyampaian habitus paling efektif secara implisit atau melalui teladan. Oleh karena itu, orang tua diharapkan mampu melakukannya secara langsung. 
Undang-Undang Sistem Pendidikan Nasional Nomor 20 Tahun 2003, Bab I Pasal 1 ayat 13, menyebutkan bahwa "pendidikan informal adalah jalur pendidikan keluarga dan lingkungan." Selanjutnya pasal 27 ayat 1, mempertegas bahwa 'kegiatan pendidikan informal yang dilakukan oleh keluarga dan lingkungan berbentuk kegiatan belajar secara mandiri”. Berdasarkan Undang-Undang di atas, secara konstitusional keberadaan jalur pendidikan secara informal atau disebut juga dengan jalur pendidikan di dalam keluarga menjadi kekuatan hukum yang legal formal. Secara hak- hak kewarga-negaraan sudah seharusnya dilaksanakan oleh semua para orang tua. Apalagi ketentuan-ketentuan secara teknis operasionalisasi memiliki ketetapan yuridis formal (Undang-Undang Republik Indonesia Nomor 20 Tahun 2003).

\section{Menyingkirkan Hambatan Kelas Bawah}

Penelitian yang dilakukan Bourdieu dan Passeron terhadap institusi pendidikan di Prancis menyingkap fakta bahwa terdapat selisih yang cukup besar antara peluang peserta didik kelas atas dan kelas bawah untuk bergabung dengan Perguruan Tinggi unggulan. Adanya kesenjangan di antara peserta didik, tidak hanya terdapat pada tahap awal ketika mereka hendak masuk institusi pendidikan formal, tetapi terjadi pula saat berada dalam proses pendidikan. Sekolah dipandang justru menjadi alat reproduksi kesenjangan sosial di antara peserta didik. Faktor penyebab reproduksi disebutkan Bourdieu, yaitu perbedaan kapital budaya peserta didik sebagai konsekuensi dari perbedaan pewarisan budaya dalam keluarga.

Gagasan Bourdieu mengenai pendekatan sosiologi dalam pendidikan menjadi suatu cara untuk meminimalisasi perbedaan pewarisan budaya antara keluarga kelas atas dan keluarga kelas bawah. Gagasannya mengenai pendekatan sosiologi menumbuhkan kesadaran bagi keluarga sebagai aktor utama pewarisan budaya dan habitus kepada anak. Keluarga diharapkan menyadari perannya sebagai basis strategi pendidikan anak sehiingga anak sungguh dipersiapkan secara kompeten agar mampu bersaingan dalam arena pendidikan formal yang hendak dimasukinya. Melalui cara ini, anak dapat dipersiapkan sebagai pelaku perubahan jenjang sosial keluarga. Contoh, seorang anak dalam keluarga petani harus dibiasakan untuk membaca buku. Di zaman ini buku bukanlah barang mahal dan langka didapatkan, sehingga bisa diakses oleh semua orang, maka kebiasaan seperti ini hendaknya ditanamkan agar anak lebih siap mengahadapi persaingan dalam arena pendidikan formal dan tidak merasa sebagai bagi terpisahkan dengan habitus yang dituntut oleh sekolah.

Dominasi simbolis yang terjadi dalam institusi pendidikan formal sebagai akibat dari kesenjangan sosial harus menjadi fokus utama pemerintah. Indonesia yang telah mencantumkan cita-cita mulia untuk mencerdaskan kehidupan bangsa dalam Pembukaan UUD 1945 harus mengupayakan terwujudnya cita-cita tersebut. Salah satu syarat yang mesti dipenuhi untuk mewujudkannya adalah kesetaraan dalam pendidikan atau pendidikan yang inklusif (tidak diskriminatif). Pemerintah mesti mengupayakan berbagai program dan kebijakan demi pencapaian ini. Upaya yang dapat dilakukan oleh pemerintah untuk menanggulangi berbagai permasalahan 
dalam bidang pendidikan yang masih sering terjadi, yakni dengan membangun wilayah pendidikan prioritas. Melalui upaya ini, peserta didik yang berasal dari kelas bawah dan desa menjadi prioritas yang harus didukung oleh tenaga pengajar dan fasilitas yang bermutu. Contoh, Program Indonesia Pintar (PIP) melalui KIP yang memberikan bantuan tunai pendidikan kepada anak usia sekolah (6-21 tahun) yang berasal dari keluarga miskin, rentan miskin: pemilik Kartu Keluarga Sejahtera, peserta PKH, yatim piatu, penyandang disabilitas, korban bencana alam/musibah. PIP merupakan bagian dari penyempurnaan program BSM. Pemeritah pun hendaknya menyediakan sekolah khusus bagi peserta didik yang telah mengalami ketertinggalan akibat putus sekolah dan hendak bersekolah kembali. Di kelas khusus ini, peserta didik yang dulunya putus sekolah dibekali dengan kemampuan komunikasi pedagogi: keterampilan berbahasa.

Perbedaan kapital budaya bukan satu-satunya penyebab reproduksi kesenjangan sosial dalam institusi pendidikan. Perbedaan kapital budaya pun menjadi penyebab reproduksi kesenjangan sosial, misalnya akses internet peserta didik kelas atas sangat terbuka karena mereka menggunakan laptop dan wifi pribadi, sedangkan peserta didik kelas bawah sulit mengakses internet karena tidak mempunyai laptop dan wifi pribadi. Antony Giddens memberikan analisis bahwa penguasaan fasilitas (ekonomi, sosial- politik, idiologi, dan fisik) sangat menentukan dominasi (Giddens, 1993). Gambaran ini terjadi dalam lingkungan sekolah. Mereka yang menguasai fasilitas (dukungan kapital ekonomi), akan menjadi kelompok dominan yang mendominasi peserta didik yang minim mendapatkan dukungan fasilitas (kapital ekonomi). Pemerintah bersama pihak sekolah mesti bekerja sama melengkapi berbagai fasilitas atau prasarana yang bisa diakses oleh semua peserta didik, sehingga kesenjangan bisa diminimalisasi. Ketersediaan perpustakaan umum dan ruang komputer yang dilengkapi fasilitas internet yang dapat diakses oleh peserta didik dari kelas bawah akan sangat membantu mereka dalam pendidikan.

Kesenjangan sosial dalam pendidikan formal merupakan persamalahan pendidikan yang tidak dapat dipandang sebelah mata. Situasi ini terjadi karena perbedaan kapital, yakni kegagalan pembentukan habitus. Segala kebiasaan buruk, misalnya bullying, diskriminasi, dan hubungan dominasi dalam pendidikan, harus segera diatasi. Pendidikan menjadi solusi paling awal untuk mengatasi berbagai persoalan tersebut, sebab pendidikan menjadi sarana memulai perubahan habitus.

\section{Kesimpulan}

Permasalahan dalam dunia pendidikan yang masih banyak ditemukan dalam sistem pendidikan Indonesia menjadi indikasi belum berjalannya program pemerintah secara efektif. Ketidakadilan dalam pendidikan, diskriminasi, komersialisasi pendidikan, pendidikan yang terlalu berfokus pada pendekatan kurikulum, sehingga mengabaikan pendekatan sosiologi, dan tingginya angka putus sekolah merupakan berbagai permasalahan yang mesti ditangani secara cepat dan serius. Penanganan terhadap permasalah ini bertujuan untuk memajukan pendidikan Indonesia. Kemajuan 
pendidikan Indonesia menjadi tanggung jawab seluruh warga negara, karena sebagai warga negara yang baik sudah sepatutnya menjunjung tinggi cita-cita bersama yang tertuang dalam konstitusi UUD 1945, "mencerdaskan kehidupan bangsa". Penulis menawarkan solusi konkret yang perlu diwujudkan demi membuka peluang yang lebih besar bagi terwujudnya cita-cita: mencerdaskan kehidupan bangsa. Kesenjangan dalam dunia pendidikan Indonesia masih sangat kental dirasakan. Seleksi masuk lembaga pendidikan formal, kurangnya pengajar bermutu di desa, fasilitas pendidikan yang dapat diakses oleh peserta didik kelas bawah masih sangat terbatas, dan sistem yang berlaku dalam pendidikan yang cenderung menguntungkan kelas atas merupakan masalah klasik dan fundamental dari permasalahan yang merongrong dunia pendidikan. Analisa mengenai komunikasi pedagogis menampakkan pentingnya peran keluarga dalam pewarisan habitus bahasa, karena menjadi elemen dasar dan penting yang akan menunjang keberhasilan anak dalam lingkungan sekolah. Pemikiran ini hendaknya menjadi motivasi bagi seluruh keluarga, pemerintah, dan masyarakat untuk mewujudkan pendidikan keluarga dan menyelenggarakan pendidikan anak usia dini sebaik-baiknya tanpa menjadikannya sebagai ladang bisnis. Pentingnya pendekatan sosiologi yang memperhitungkan latar belakang peserta didik merupakan masukan yang sangat berarti bagi para pengajar. Pengetahuan latar belakang peserta didik membantu para pengajar dalam memahami karakter, kelebihan, dan kekurangan peserta didik, sehingga dapat menentukan solusi atas hambatan yang dialami peserta didik.

Pengembangan strategi pendidikan dalam keluarga, pembentukan pendidikan prioritas bagi kelas bawah dan desa yang didukung ketersedian para pengajar yang bermutu, pendidikan inklusi, fasilitas pendidikan yang memadai dan dapat dijangkau oleh kelas bawah merupakan langkah konkret yang dapat diwujudkan demi menyingkirkan hambatan peserta didik kelas bawah dan membuka kesempatan yang semakin besar untuk pemerataan pendidikan bermutu di Indonesia. Pada akhirnya, citacita negara untuk mencerdaskan kehidupan bangsa dapat diperjuangkan dan diwujudkan bersama. 


\section{BIBLIOGRAFI}

Bertens, Kees. (2014). Sejarah Filsafat Kontemporer Perancis. Jakarta: Gramedia.Google Scholar

Edkins, Jenny, Williams, Nick Vaughan, \& Radike, T. (2010). Teori-teori Kritis Menantang Pandangan Utama Studi Politik Internasional. Yogyakarta: Pustaka Pelajar. Google Scholar

Fashri, Fauzi. (2014). Pierre Bourdieu: Menyingkap Kuasa Simbol. Yogyakarta: Jalasutra. Google Scholar

Giddens, Anthony. (1993). New rules of sociological method: A positive critique of interpretative sociologies. Stanford University Press. Google Scholar

Haryatmoko, Johannes. (2016). Etika politik dan kekuasaan. Kompas. Repositori IAIN Batusangkar. Google Scholar

Karnanta, Kukuh Yudha. (2013). Paradigma teori arena produksi kultural sastra: Kajian terhadap pemikiran Pierre Bourdieu. Jurnal Poetika, 1(1). Google Scholar

Lubis, Akhyar Yusuf. (2014). Postmodernisme: teori dan metode. Jakarta: Rajawali Pers. Google Scholar

Nikmah, Cahya Anggraeni. (2020). Sanksi Pidana Terhadap Pengguna Jasa Prostitusi Online Perspektif Fiqh Jināyah. Iain Purwokerto. Google Scholar

Palmer, Jason, \& Cooper, Ian. (2013). United Kingdom housing energy fact file 2013. Department of Energy \& Climate Change, Prepared under Contract to DECC by Cambridge Architectural Research, Eclipse Research Consultants and Cambridge Energy. The Views Expressed Are Not Necessarily DECC'sp, 172. Google Scholar

Poulin Jessica. (2015). Pierre Bourdieu's Homo Academicus:Objectifying the Academic Object. California: Stanford University Press.

Purwanto, Hadi (ed). (2016). Membaca Pikiran Pierre Bourdieu. Jogjakarta: Kreasi Wacana. Google Scholar

Rawolle, Shaun, \& Lingard, Bob. (2013). Bourdieu and educational research: Thinking tools, relational thinking, beyond epistemological innocence. In Social theory and education research (pp. 129-149). Routledge. Google Scholar

Ritzer, George \&. Goodman. (2012). Teori Sosiologi Klasik-Post Modern Edisi Terbaru. Yogyakarta: Kreasi Wacana.

Rusdiarti, Suma Riella. (2003). Bahasa, Pertarungan Simbolik dan Kekuasaan. Jurnal Basis, Edisi Khusus Pierre Bourdieu, (11), 12. Google Scholar 
Siregar, Mangihut. (2016). Teori "Gado-Gado" Pierre-Felix Bourdieu. An1mage. Jurnal Studi Kultural. Google Scholar

Suyanto, Bagong, dkk (eds). (2013). Filsafat Sosial. Malang: Aditya Media Publishing.

Syaeful, Heri, \& Sucipta, Sucipta. (2013). Penentuan Koefisien Hidraulik pada Tapak NSD, Serpong, Berdasarkan Metoda Uji Permeabilitas In-Situ. Eksplorium, 34(1), 35-50. Google Scholar

Undang-Undang Republik Indonesia Nomor 20 Tahun 2003. (2003). Sistem Pendidikan Nasional. Undang-Undang Republik Indonesia Nomor 20 Tahun 2003.

Weber, Max. (2012). Sosiologi Agama. Jogjakarta: IRCciSoD. Google Scholar

Zulaikhah, Siti. (2019). Penguatan Pendidikan Karakter Melalui Pendidikan Agama Islam Di Smpn 3 Bandar Lampung. Al-Tadzkiyyah: Jurnal Pendidikan Islam, 10(1), 83-93. Google Scholar

\section{Copyright holder:}

Ardyanto Allolayuk (2021)

First publication right:

Syntax Idea

This article is licensed under:

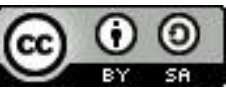

